\title{
PENGGUNAAN MEDIA PEMBELAJARAN BERBASIS KOMPUTER DAN SIKAP INOVATIF TERHADAP HASIL BELAJAR TEKNOLOGI INFORMASI DAN KOMUNIKASI
}

\author{
Danny Abrianto dan Harun Sitompul \\ SMK Namira Tech Nusantara Medan dan PPs Universitas Negeri Medan \\ danny.abrianto@gmail.com
}

\begin{abstract}
Abstrak: Penelitian ini bertujuan untuk mengetahui keunggulan penggunaan media pembelajaran radio streaming dibandingkan dengan komputer dalam mempengaruhi hasil belajar TIK, untuk mengetahui hasil keunggulan TIK siswa yang memiliki sikap inovatif positif lebih tinggi dibandingkan dengan sikap inovatif negatif; interaksi antara media pembelajaran radio streaming dan komputer dengan sikap inovatif siswa dalam hasil belajar TIK. Metode penelitian menggunakan metode quasi eksperimen dengan desain penelitian faktorial $2 \times 2$, sedangkan teknik analisis data menggunakan ANAVA dua jalur pada taraf signifikansi $\alpha=0.05$. Hasil penelitian diperoleh bahwa; hasil belajar TIK siswa yang dibelajarkan dengan menggunakan media pembelajaran radio streaming lebih tinggi dibandingkan dengan computer, hasil belajar TIK siswa yang memiliki sikap inovatif positif lebih tinggi daripada sikap inovatif negative, terdapat interaksi antara media pembelajaran radio streaming dalam pembelajaran dengan sikap inovatif siswa, artinya bahwa siswa yang memiliki sikap inovatif positif dengan menggunakan media pembelajaran radio streaming maupun komputer akan memiliki hasil belajar TIK lebih tinggi dibandingkan dengan siswa yang memiliki sikap inovatif negatif.
\end{abstract}

Kata Kunci: media pembelajaran radio streaming, pembelajaran komputer, sikap inovatif, hasil belajar TIK

\begin{abstract}
This study aims to determine the benefits of the use of instructional media streaming radio compared with the computer affecting ICT learning outcomes, to know the results of ICT excellence of students who have a positive attitude innovative higher than the negative innovative attitude; interaction between instructional media streaming radio and a computer with an innovative attitude in the students' learning outcomes ICT. Method using quasi-experimental research design with a 2x2 factorial study, while data analysis techniques using ANOVA two lanes at the significance level $\alpha=0: 05$. The results showed that; ICT learning outcomes of students who learned with use of instructional media streaming radio is higher than the computer, ICT learning outcomes of students who have a positive attitude is higher than the innovative innovative attitude is negative, there is an interaction between media streaming radio learning in students' learning with innovative attitude, meaning that students who have a positive attitude with the innovative use of instructional media streaming radio and the computer will have higher ICT learning outcomes than students who have negative innovative attitude.
\end{abstract}

Keywords : instructional media streaming radio, computer learning, innovative attitude, ICT learning outcomes

\section{PENDAHULUAN}

Media komunikasi adalah suatu media ataupun alat bantu yang digunakan oleh suatu organisasi untuk mencapai efisiensi dan efektivitas kerja dengan hasil yang maksimal. Salah satu alat komunikasi tersebut yaitu Radio menjadi media pendidikan yang berguna bagi semua bentuk yang berhubungan dengan pendidikan, karena dapat memperkaya pengalaman pendidikan dan juga ide-ide yang kreatif. Dengan demikian, alat ini memiliki potensi dan kekuatan yang berpengaruh dalam pendidikan.

Penggunaan pembelajaran melalui media streaming di Indonesia masih sangat sedikit digunakan dalam dunia pendidikan, hal 
ini dikarenakan kapasitas koneksi internet yang kurang memadai, apalagi pembelajaran yang berbasis visual streaming seperti penggunan media Youtube yang sangat besar kapasitasnya untuk digunakan. Oleh sebab itu, media pembelajaran berbasis radio streaming digunakan karena penggunaan software streaming yang tidak banyak menghabiskan quota koneksi internet, mudah digunakan, bisa menjadi pembelajaran yang menyenangkan karena dipadukan antara pembelajaran dengan musik atau lagu yang di request serta adanya sarana interaktif (live streaming) yang dikolaborasikan dengan media lainnya, seperti yahoo messenger, skype messenger dan hasil siarannya pun bisa direkam secara otomatis agar bisa dimanfaatkan kembali.

Menurut Yustina (2010) radio streaming adalah radio yang bisa didengarkan lewat internet. Secara umum Radio mempunyai kegunaan: (a) memperjelas pesan yang diterima; (b) mengatasi keterbatasan ruang, waktu tenaga dan daya indra; (c) menimbulkan gairah belajar, interaksi lebih langsung antara murid dengan sumber belajar; (d) memungkinkan anak belajar mandiri sesuai dengan bakat dan kemampuan auditori dan kinestetiknya; dan (e) memberi rangsangan yang sama, mempersamakan pengalaman dan menimbulkan persepsi yang sama.

Radio khususnya radio streaming menjadi media pendidikan dalam berbagai aspeknya. Karena media ini memang memiliki potensi dan kekuatan yang amat berpengaruh dalam dunia kependidikan. Radio Streaming sebagai pemberi informasi dan alat yang mendidik, muatan sajiannya dapat meningkatkan pengetahuan, keterampilan, moral, dan akhlak seseorang.

Secara khusus di SMK Namira Tech

Nusantara menurut pengamatan penulis bahwa penggunaan media pembelajaran yang dilakukan oleh guru pada umumnya belum secara maksimal. Begitu pula dengan keterbatasan waktu yang disediakan sehingga permasalahan ini akan memberikan pengaruh pada mutu pendidikan pada siswa sebagai siswa. Untuk itu dibutuhkan penelitian media pembelajaran yang baru yaitu media pembelajaran berbasis radio streaming dalam meningkatkan hasil belajar TIK di sekolah.

Rendahnya tingkat pemanfaatan TIK di sekolah disebabkan tidak semua sekolah mempunyai sarana TIK dan tidak semua sekolah menggunakan media pembelajaran berbasis radio streaming dan kalaupun ada penggunaannya kurang optimal (utilitas rendah) www.scribid.com/doc/3582545/TIKUntuk-Pembelajaran (diakses tanggal 30 September 2009). TIK telah berkembang seiring dengan globalisasi sehingga interaksi dan penyampaian informasi akan berlangsung dengan cepat. Dampak dari globalisasi ini dapat berdampak positif dan negatif pada suatu negara. Teknologi informasi saat ini telah mematahkan jarak dalam berkomunikasi, hal ini dapat dilihat dengan adanya internet yang setiap saat, kapan dan dimana saja dapat mengakses informasi dari belahan dunia manapun. Namun keadaan ini juga telah menimbulkan adanya perbedaan mencolok (digital-divide) antara yang mampu dan yang tidak mampu dalam akses penggunaan TIK. Dengan adanya globalisasi yang tidak terelakkan ini, mau tidak mau menimbulkan persaingan antar bangsa sehingga menuntut adanya pengembangan kualitas sumber daya manusia. Pendidikan adalah salah satu hal penting dalam pengembangan sumber daya manusia.

Mata pelajaran TIK merupakan mata pelajaran yang baru dimasukkan dalam kurikulum sistem pendidikan nasional. Dengan pesatnya perkembangan teknologi diberbagai aspek kehidupan sekarang ini sudah semestinya mata pelajaran ini diperkenalkan, dipraktekkan dan dikuasai siswa sedini mungkin agar mereka memiliki bekal untuk menyesuaikan diri dalam kehidupan global yang ditandai dengan perubahan yang sangat cepat. Dengan demikian, perlu adanya media pembelajaran yang baru yang harus diterapkan dalam meningkatkan mata pelajaran TIK di sekolah. Dalam hal menghadapi perubahan yang begitu cepat tersebut maka diperlukan kemampuan dan kemauan belajar sepanjang hayat dengan cepat dan cerdas. Hasil-hasil TIK banyak membantu manusia untuk dapat belajar secara cepat. Oleh karena itu, selain sebagai dari kehidupan sehari-hari, media pembelajaran berbasis radio streaming dapat digunakan dalam mata pelajaran TIK yang pada akhirnya dapat mengadaptasi siswa dengan lingkungan dan dunia kerja.

Hasil pengamatan yang telah dilakukan pada siswa kelas $\mathrm{X}$ semester II SMK Namira Tech Nusantara Tahun Pembelajaran 2011/2012 Medan pada saat pembelajaran TIK di dalam kelas, dijumpai adanya beberapa kesulitan dalam menyerap 
materi yang diceramahkan atau dijelaskan oleh guru. Kesulitan yang dialami adalah, pada saat proses pembelajaran berlangsung guru menyampaikan materi dengan materi konvensional, yaitu dengan cara menjelaskan materi kemudian siswa akan mencatat hal-hal penting dan setelah materi diselesaikan pada pertemuan berikutnya guru akan membawa siswa ke ruang komputer (media) untuk mempraktikkan materi yang telah disampaikan pada minggu yang lalu. Pada saat praktik, guru akan menjadi fasilitator untuk mengarahkan dan membimbing siswa pada saat pelaksanaan mengerjakan tugastugas latihan yang diberikan oleh guru. Dalam kondisi yang seperti ini, siswa yang memiliki konsentrasi dan keinginan untuk belajar akan memperhatikan penjelasan dari guru, tetapi bagi siswa yang tidak memiliki minat belajar akan menjadi bosan. Keadaan ini harus segera ditanggulangi dengan menjadikan satu pembelajaran yang tidak hanya membuat siswa duduk diam dan mendengar, tetapi membuat mereka belajar mandiri dengan menggunakan pembelajaran berbasis komputer yaitu dengan menggunakan media pembelajaran berbasis radio streaming.

Sikap inovatif merupakan salah satu dari karakteristik siswa yang bisa melahirkan sesuatu yang baru, baik berupa gagasan maupun karya nyata, yang realatif berbeda dengan apa yang sebelumnya telah ada. Sikap inovatif siswa juga merupakan informasi yang penting bagi guru untuk memberikan pembelajaran, karena dengan mengetahui sikap inovatif dari siswa inilah guru dapat menentukan strategi pembelajaran yang tepat. Pada mata pelajaran TIK sikap inovatif siswa sangat penting untuk mencapai keberhasilan pembelajaran si siswa untuk mengukur sejauh mana dapat menampung pembelajaran dan mengaktualisasikan dengan mempraktekkan dan menghasilkan satu karya yang diharapkannya pada tujuan pembelajaran.

Menurut Rusman (2011:90) ruang lingkup mata pelajaran TIK meliputi aspekaspek sebagai berikut: (1) perangkat keras dan perangkat lunak yang digunakan untuk mengumpulkan, menyimpan, memanipulasi dan menyajikan informasi, dan (2) penggunaan alat bantu untuk memproses dan memindah data dari satu perangkat ke perangkat lainnya. Karakteristik mata pelajaran TIK (Diknas: 2006) adalah sebagai berikut: (1) TIK merupakan keterampilan menggunakan komputer meliputi perangkat keras dan perangkat lunak. Namun demikian, TIK tidak sekedar terampil, tetapi lebih memerlukan kemampuan intelektual; (2) materi TIK berupa tema-tema esensial, aktual serta global yang berkembang dalam kemajuan teknologi pada masa kini, sehingga mata pelajaran TIK merupakan pelajaran yang dapat mewarnai perkembangan perilaku dalam kehidupan; (3) tema-tema esensial dalam TIK merupakan perpaduan dari cabangcabang Ilmu Komputer, Matematika, Teknik Elektro, Teknik Elektronika, Telekomunikasi, Sibernetika dan Informatika itu sendiri. Tematema esensial tersebut berkaitan dengan kebutuhan pokok akan informasi sebagai ciri abad 21 seperti pengolah kata, spreadsheet, presentasi, basis data, internet dan e-mail; dan (4) materi TIK dikembangkan dengan pendekatan interdisipliner dan multidimensional. Dikatakan interdisipliner karena melibatkan berbagai disiplin ilmu, dan dikatakan multidimensional karena mencakup berbagai aspek kehidupan masyarakat.

Tujuan pembelajaran TIK adalah agar siswa memiliki kemampuan sebagai berikut: (1) memahami TIK; (2) mengembangkan keterampilan untuk memanfaatkan TIK; (3) membangun dan menerapkan informasi, pengetahuan dan teknologi secara logis, kritis, kreatif dan inovatif; (4) mengembangkan sikap kritis, kreatif, apresiatif dan mandiri dalam penggunaan TIK; dan (5) berkomunikasi dan berinteraksi secara efektif dan santun melalui berbagai cara termasuk pemanfaatan teknologi informasi.

Radio Streaming adalah radio yang bisa didengarkan lewat internet. Secara umum Radio mempunyai kegunaan: (a) memperjelas pesan yang diterima; (b) mengatasi keterbatasan ruang, waktu tenaga dan daya indra; (c) menimbulkan gairah belajar, interaksi lebih langsung antara murid dengan sumber belajar; (d) memungkinkan anak belajar mandiri sesuai dengan bakat dan kemampuan auditori dan kinestetiknya; dan (e) memberi rangsangan yang sama, mempersamakan pengalaman dan menimbulkan persepsi yang sama.

Pembelajaran berbasis komputer merupakan program pembelajaran dengan menggunakan software komputer (CD pembelajaran) berupa program komputer yang berisi tentang muatan pembelajara meliputi: judul, tujuan, materi pembelajaran, dan evaluasi pembelajaran. Hal tersebut sejalan dengan apa yang dikemukakan oleh Robert 
Heinich, Molenda, dan James D. Russel (1985:226) yang menyatakan bahwa: "Computer system can delivery instruction by allowing them to interact with the lesson programmed into the system; this is refered to computer based instruction". Sistem komputer dapat menyampaikan pembelajaran secara individual dan langsung kepada para siswa dengan cara berinteraksi dengan mata pelajaran yang diprogramkan ke dalam sistem komputer, inilah yang disebut dengan media pembelajaran berbasis komputer.

Secara konsep pembelajaran berbasis komputer adalah bentuk penyajian bahanbahan pembelajaran dan keahlian atau keterampilan dalam satuan unit-unit kecil, sehingga mudah dipelajari dan dipahami oleh siswa. PBK merupakan suatu bentuk pembelajaran yang menempatkan komputer sebagai piranti sistem pembelajaran individual, dimana siswa dapat berinteraksi langsung dengan sistem komputer yang sengaja dirancang dan dimanfaatkan oleh guru. Kontrol pembelajaran dalam pembelajaran berbasis komputer ini sepenuhnya ada di tangan siswa (student center), karena pembelajaran berbasis komputer menerapkan pola pembelajaran bermedia, yaitu secara utuh sejak awal hingga akhir menggunakan piranti sistem komputer (CD interaktif).

Mar'at (1984:10) berpendapat bahwa: "Sikap diartikan sebagai suatu konstruk untuk memungkinkan telihatnya suatu aktivitas", dari uraian bermacam pengertian sikap muncullah berbagai problema yang berpangkal pada pembawaan-pembawaan salah satunya dari unsur kepribadian yaitu sikap yang berkaitan dengan motif dan mendasari tingkah laku seseorang. Diungkapkan lebih jauh, bahwa objek psikologis itu berupa simbol ungkapan, semboyan, pendirian, dan idealisme yang berpengaruh terhadap individu, dimana individu yang bersangkutan cenderung mempunyai pandangan yang sama atau berbeda terhadap objek tersebut, bila dibandingkan dengan individu lain. Sejalan dengan pendapat di atas, Newcomb dalam Mar'at (1981:11) berpendapat, bahwa: "Sikap merupakan suatu kesatuan kognisi, afeksi dan konasi yang mempunyai valensi dan akhirnya berintegrasi ke dalam pola yang lebih luas".

Menurut Roger (1983) memberikan arti inovasi sebagai: (a) tindakan atau proses pembaruan; (b) sesuatu yang baru diperkenalkan: strategi, kebiasaan dan cara melaksanakan sesuatu. Inovasi adakalanya diartikan sebagai penemuan, tetapi berbeda maknanya dengan penemuan dalam arti discovery dan invensi. Discovery mempunyai makna penemuan sesuatu yang sesuatu itu telah ada sebelumnya, tetapi belum diketahui orang. Invensi adalah penemuan yang benarbenar baru sebagai hasil kreasi mausia; contohnya teori belajar, mode busana, dan sebagainya. Inovasi adalah suatu ide, produk, metode, dan seterusnya yang dirasakan sebagai sesuatu yang baru, baik berupa hasil discovery atau inovasi yang digunakan untuk tujuan tertentu. Pengertian baru disini, mengandung makna bukan sekedar baru diketahui oleh pikiran (cognitive) melainkan juga baru karena belum dapat diterima secara luas oleh seluruh warga masyarakat dalam arti sikap (attitude) dan juga baru dalam pengertian belum diterima dan diterapkan oleh seluruh warga masyarakat setempat.

Tujuan penelitian dalam penelitian ini adalah sebagai berikut: (1) Untuk mengetahui keunggulan penggunaan media pembelajaran berbasis radio streaming, dibandingkan dengan penggunaan media pembelajaran berbasis komputer dalam mempengaruhi hasil belajar TIK; (2) Untuk mengetahui hasil keunggulan TIK siswa yang memiliki sikap inovatif positif lebih tinggi dibandingkan dengan siswa yang memiliki sikap inovatif negatif; (3) Interaksi antara media pembelajaran menggunakan media pembelajaran berbasis radio streaming dan media pembelajaran berbasis komputer dengan sikap inovatif siswa dalam hasil belajar TIK.

\section{METODE PENELITIAN}

Populasi dalam penelitian ini adalah seluruh siswa kelas X SMK Namira Tech Nusantara Tahun Pelajaran 2011/2012. Teknik pengambilan sampel pada penelitian ini adalah dengan menggunakan teknik purposive sampling dimana penelitian ini dilakukan pada seluruh populasi yang ada, yang langsung terfokus pada target.

Desain penelitian ini menggunakan pendekatan eksperimen yang merupakan penelitian yang berusaha mencari dan menguji pengaruh suatu variabel atau lebih terhadap variabel yang lain. Penelitian ini bersifat Quasi Experiment desain faktorial 2x2. Melalui desain ini akan dibandingkan 
pengaruh media pembelajaran berbasis radio streaming dan media pembelajaran berbasis komputer terhadap hasil belajar TIK ditinjau dari sikap inovatif. Media pembelajaran berbasis radio streaming dan media pembelajaran berbasis komputer diperlakukan pada kelompok eksperimen siswa dengan sikap inovatif dan negatif.

\section{HASIL DAN PEMBAHASAN \\ Hasil}

Tabel 1. Rangkuman Data Hasil Perhitungan Analisis Deskriptif

\begin{tabular}{|c|c|c|c|c|}
\hline \multicolumn{2}{|c|}{ Sikap Inovatif } & \multicolumn{3}{|c|}{ Media Pembelajaran } \\
\cline { 2 - 5 } & Radio Streaming $\left(\boldsymbol{A}_{\mathbf{1}}\right)$ & Komputer $\left(\boldsymbol{A}_{\mathbf{2}}\right)$ & Total \\
\hline Positif & $\mathrm{N}$ & 12 & 13 & 25 \\
$\left(\boldsymbol{B}_{\mathbf{1}}\right)$ & $\sum X$ & 388 & 347 & 735 \\
& $\sum X^{2}$ & 12570 & 9325 & 21895 \\
& $\bar{X}$ & 32,33 & 26,5 & 58,83 \\
& $\mathrm{~S}$ & 1,8 & 2,44 & 4,24 \\
\hline Negatif & $\mathrm{N}$ & 15 & 15 & 30 \\
$\left(\boldsymbol{B}_{\mathbf{2}}\right)$ & $\sum X$ & 292 & 320 & 612 \\
& $\sum X^{2}$ & 5758 & 6950 & 12708 \\
& $\bar{X}$ & 19,37 & 21,5 & 40,87 \\
& $\mathrm{~S}$ & 3,23 & 2,92 & 6,15 \\
\hline Total & $\mathrm{N}$ & 27 & 28 & 55 \\
& $\sum X$ & 680 & 667 & 1347 \\
& $\sum X^{2}$ & 18328 & 16275 & 34603 \\
& $\bar{X}$ & 51,7 & 48 & 99,7 \\
& $\mathrm{~S}$ & 5,03 & 5,36 & 10,39 \\
\hline
\end{tabular}

Untuk keperluan pengujian hipotesis dengan menggunakan teknik analisis varians dua jalur faktorial 2x2, uji Scheffe diperlukan untuk menghitung harga rata-rata tiap kelompok yang disajikan data hasil belajar TIK siswa pada Tabel 1. Setelah data diolah dengan Anava 2 jalur faktorial 2x2, maka diperoleh hasil analisis seperti ditunjukkan pada Tabel 2.

Tabel 2. Ringkasan Perhitungan Anava Faktorial 2x2

\begin{tabular}{|c|c|c|c|c|c|c|}
\hline Sumber Varians & $\mathrm{dk}$ & JK & RJK & $F_{\text {hitung }}$ & $F_{\text {tabel } 0,05}$ & $\mathrm{~F}_{\text {tabel } 0,01}$ \\
\hline Antar Kelompok (A) & 1 & 25,45 & 25,45 & 4,56 & \multirow{3}{*}{4,03} & \multirow{3}{*}{7,17} \\
\hline Dalam Kelompok (B) & 1 & 1104,55 & 1104,55 & 198,30 & & \\
\hline Interaksi $(\mathrm{AxB})$ & 1 & 1329,25 & 1329,25 & 238,64 & & \\
\hline Galat & 51 & 284,5 & 5,57 & & & \\
\hline Total & 54 & 2743,75 & & & & \\
\hline
\end{tabular}

Pada Tabel 2 menunjukkan $F_{\text {hitung }}>$ $\mathrm{F}_{\text {tabel }}=4,03$, dapat disimpulkan adanya interaksi antara menggunakan media pembelajaran berbasis radio streaming dengan sikap inovatif yang mempengaruhi hasil belajar TIK siswa.

Pengujian dilakukan terhadap hipotesis statistik yang dirumuskan sebagai berikut:
$\mathrm{H}_{0}: \mu \mathrm{A} 1=\mu \mathrm{A} 2$

$\mathrm{H}_{\mathrm{a}}: \mu \mathrm{A} 1>\mu \mathrm{A} 2$

Pernyataan hipotesis tersebut adalah :

a. $\mathrm{H}_{0}$ : Hasil belajar TIK siswa yang menggunakan media pembelajaran berbasis

radio streaming sama dengan hasil belajar TIK siswa yang menggunakan media pembelajaran berbasis komputer. 
b. $\mathrm{H}_{\mathrm{a}}$ : Hasil belajar TIK siswa yang menggunakan media pembelajaran berbasis

radio streaming lebih tinggi dari pada hasil belajar TIK siswa yang menggunakan media siswa yang menggunakan media pembelajaran berbasis komputer.

Ringkasan anava faktorial $2 \times 2$ pada Tabel 2 menunjukkan bahwa $F_{\text {hitung }}$ lebih besar dari $F_{\text {tabel }}\left(F_{\text {hitung }}=4,56>F_{\text {tabel }}=4,03\right)$. Ini berarti Ho ditolak, sebaliknya menerima $\mathrm{Ha}$ pada taraf signifikansi $\dot{\alpha}=0,05$. Dengan demikian temuan penelitian menyimpulkan, bahwa hipotesis penenlitian yang menyatakan: hasil belajar TIK siswa yang menggunakan media pembelajaran berbasis radio streaming lebih tinggi daripada siswa yang dibelajarkan menggunakan media pembelajaran berbasis komputer teruji kebenarannya.

Perbedaan hasil belajar TIK dari siswa yang memiliki sikap inovatif positif dan siswa yang memiliki sikap inovatif negatif dilakukan dengan analisis varians. Pengujian dilakukan terhadap hipotesis yang dirumuskan sebagai berikut:

$$
\begin{aligned}
& \mathrm{H}_{0}: \mu \mathrm{A} 1=\mu \mathrm{A} 2 \\
& \mathrm{H}_{\mathrm{a}}: \mu \mathrm{A} 1>\mu \mathrm{A} 2
\end{aligned}
$$

a. $\mathrm{H}_{0}$ : Hasil belajar TIK siswa yang memiliki sikap inovatif positif sama dengan

hasil belajar TIK siswa yang memiliki sikap inovatif negatif.

b. $\mathrm{H}_{\mathrm{a}}$ : Hasil belajar TIK sisa yang memiliki sikap inovatif positif lebih tinggi

daripada hasil belajar TIK siswa yang memiliki sikap inovatif negatif.

Ringkasan anava faktorial $2 \times 2$ pada Tabel 2 menunjukkan bahwa $F_{\text {hitung }}$ lebih besar dari $F_{\text {tabel }}\left(F_{\text {hitung }}=198,30>F_{\text {tabel }}=4,03\right)$. Ini berarti $\mathrm{H}_{0}$ ditolak, sebaliknya menerima $\mathrm{H}_{\mathrm{a}}$ pada taraf signifikansi $\dot{\alpha}=0,05$. Dengan demikian temuan penelitian menyimpulkan, bahwa hipotesis penenlitian yang menyatakan: hasil belajar TIK siswa yang memiliki sikap inovatif positif lebih tinggi daripada siswa yang memiliki sikap inovatif negatif teruji kebenarannya.

Pengujian dilakukan terhadap hipotesis statistik yang dirumuskan sebagai berikut:

$$
\mathrm{H}_{0}: \text { Interaksi }(\mathrm{B} \times \mathrm{T})=0
$$

$\mathrm{H}_{\mathrm{a}}$ : Interaksi $(\mathrm{B} \times \mathrm{T}) \neq 0$

a. $\mathrm{H}_{0}$ : Tidak terdapat interaksi pembelajaran menggunakan media pembelajaran

berbasis radio streaming dan sikap inovatif terhadap hasil belajar TIK siswa

b. $\mathrm{H}_{\mathrm{a}}$ : Terdapat interaksi pembelajaran menggunakan media pembelajaran berbasis radio streaming dan sikap inovatif terhadap hasil belajar TIK siswa.

Ringkasan anava faktorial $2 \times 2$ pada Tabel 2 menunjukkan bahwa $F_{\text {hitung }}$ lebih besar dari $F_{\text {tabel }}\left(F_{\text {hitung }}=238,64>F_{\text {tabel }}=4,03\right)$. Ini berarti $\mathrm{H}_{0}$ ditolak, sebaliknya menerima $\mathrm{H}_{\mathrm{a}}$ pada taraf signifikansi $\alpha=0,05$. Dengan demikian temuan penelitian menyimpulkan, bahwa hipotesis penenlitian yang menyatakan: adanya interaksi antara media pembelajaran berbasis radio streaming dan sikap inovatif dalam mempengaruhi hasil belajar TIK teruji kebenarannya.

Sehubungan dengan adanya interaksi maka perlu dilakukan uji lanjutan dengan uji Scheffe. Uji Scheffe dilakukan karena data untuk setiap sel adalah tidak sama, hasil pengujian dengan menggunakan uji Scheffe dapat di lihat dalam Tabel 3.

Tabel 3. Ringkasan Hasil Pengujian Dengan Menggunakan Uji Scheffe

\begin{tabular}{|c|c|c|c|}
\hline Hipotesis Statistik & $\mathrm{F}_{\text {hitung }}$ & $\mathrm{F}_{\text {tabel }}$ & Keterangan \\
\hline $\mathrm{H}_{0}: \mu \mathrm{A}_{1} \mathrm{~B}_{1=}=\mathrm{A}_{2} \mathrm{~B}_{1}$ & 6,20 & 3,70 & Signifikan \\
\hline $\mathrm{H}_{0}: \mu \mathrm{A}_{1} \mathrm{~B}_{1=} \mu \mathrm{A}_{1} \mathrm{~B}_{2}$ & 14,24 & 3,70 & Signifikan \\
\hline $\mathrm{H}_{0}: \mu \mathrm{A}_{1} \mathrm{~B}_{1=}=\mathrm{A}_{2} \mathrm{~B}_{2}$ & 11,90 & 3,70 & Signifikan \\
\hline $\mathrm{H}_{0}: \mu \mathrm{A}_{2} \mathrm{~B}_{1=} \mu \mathrm{A}_{1} \mathrm{~B}_{2}$ & 8,10 & 3,70 & Signifikan \\
\hline $\mathrm{H}_{0}: \mu \mathrm{A}_{2} \mathrm{~B}_{1=}=\mathrm{A}_{2} \mathrm{~B}_{2}$ & 9,65 & 3,70 & Signifikan \\
\hline $\mathrm{H}_{0}: \mu \mathrm{A}_{1} \mathrm{~B}_{2}=\mu \mathrm{A}_{2} \mathrm{~B}_{2}$ & $-2,50$ & 3,70 & Tidak Signifikan \\
\hline
\end{tabular}

Dari hasil uji Scheffe diperoleh kesimpulan, yaitu: (1) rata-rata hasil belajar TIK yang dibelajarkan menggunakan media pembelajaran berbasis radio streaming dengan sikap inovatif positif dibandingkan dengan rata-rata hasil belajar TIK yang dibelajarkan dengan menggunakan media pembelajaran berbasis komputer yang 
memiliki sikap inovatif positif menghasilkan nilai $F_{\text {hitung }}$ sebesar 6,20. Di banding dengan nilai $F_{\text {tabel }}$ sebesar 3,70, dengan demikian $F_{\text {hitung }}=6,20>F_{\text {tabel }}=3,70$. Ini berarti adanya perbedaan hasil belajar TIK antara siswa yang dibelajarkan dengan media pembelajaran berbasis radio streaming dengan siswa yang dibelajarkan dengan media pembelajaran berbasis komputer, (2) rata-rata hasil belajar TIK siswa yang dibelajarkan menggunakan media pembelajaran berbasis radio streaming dengan siswa yang memiliki sikap inovatif positif dibandingkan dengan hasil belajar TIK siswa yang dibelajarkan dengan menggunakan media pembelajaran berbasis radio streaming yang memiliki sikap inovatif negatif menunjukkan terdapat adanya pengaruh. Hasil perhitungan $\mathrm{F}_{\text {hitung }}$ diperoleh sebesar 14,24 dan nilai $F_{\text {tabel }}$ sebesar 3,70 , dengan demikian $F_{\text {hitung }}=14,24>F_{\text {tabel }}=3,70,(3)$ rata-rata hasil belajar TIK siswa yang dibelajarkan menggunakan media pembelajaran berbasis radio streaming dengan siswa yang memiliki sikap inovatif positif dibandingkan dengan hasil belajar TIK siswa yang dibelajarkan dengan menggunakan media pembelajaran berbasis komputer dengan siswa yang memiliki sikap inovatif negatif menunjukkan adanya pengaruh antara hasil belajar TIK siswa yang dibelajarkan dengan media pembelajaran berbasis radio streaming dengan siswa yang dibelajarkan dengan media pembelajaran berbasis komputer. Hasil perhitungan $\mathrm{F}_{\text {hitung }}$ diperoleh sebesar 11,90dan nilai $F_{\text {tabel }}$ sebesar 3,70 , dengan demikian $\mathrm{F}_{\text {hitung }}=11,90>\mathrm{F}_{\text {tabel }}=3,70$, (4) rata-rata hasil belajar TIK siswa yang dibelajarkan menggunakan media pembelajaran berbasis komputer dengan siswa yang memiliki sikap inovatif positif dibandingkan dengan hasil belajar TIK siswa yang dibelajarkan dengan menggunakan media pembelajaran berbasis radio streaming yang memiliki sikap inovatif negatif menunjukkan adanya pengaruh. Hasil perhitungan $F_{\text {hitung }}$ diperoleh sebesar 8,10 dan nilai $F_{\text {tabel }}$ sebesar 3,70, dengan demikian $\mathrm{F}_{\text {hitung }}=8,10>\mathrm{F}_{\text {tabel }}=3,70$, (5) rata-rata hasil belajar TIK yang dibelajarkan menggunakan media pembelajaran berbasis komputer dengan siswa yang memiliki sikap inovatif positif dan negatif menghasilkan nilai $F_{\text {hitung }}$ sebesar 9,65. Di banding dengan nilai $\mathrm{F}_{\text {tabel }}$ sebesar 3,70, dengan demikian $\mathrm{F}_{\text {hitung }}=9,65>$ $F_{\text {tabel }}=3,70$. Ini berarti terdapat pengaruh hasil belajar TIK antara siswa yang dibelajarkan dengan menggunakan media berbasis komputer dengan siswa yang memiliki sikap inovatif positif dan negatif (6) rata-rata hasil belajar TIK yang dibelajarkan menggunakan media pembelajaran berbasis radio streaming dengan sikap inovatif negatif dibandingkan dengan rata-rata hasil belajar TIK yang dibelajarkan dengan menggunakan media pembelajaran berbasis komputer yang memiliki sikap inovatif negatif menghasilkan nilai $F_{\text {hitung }}$ sebesar $-2,50$. Di banding dengan nilai $F_{\text {tabel }}$ sebesar 3,70, dengan demikian $F_{\text {hitung }}=-2,50<F_{\text {tabel }}=3,70$. Ini berarti tidak terdapat pengaruh hasil belajar TIK antara siswa yang dibelajarkan dengan media pembelajaran berbasis radio streaming dengan siswa yang dibelajarkan dengan media pembelajaran berbasis komputer.

Hasil pengujian hipotesis di atas, menunjukkan adanya interaksi antara siswa yang dibelajarkan menggunakan media pembelajaran berbasis radio streaming dan sikap inovatif terhadap hasil belajar TIK. Interaksi antara pembelajaran menggunakan media pembelajaran berbasis radio streaming dan media pembelajaran komputer dengan sikap inovatif tersebut dapat divisiualisasikan dalam bentuk grafis pada Gambar 1 . 


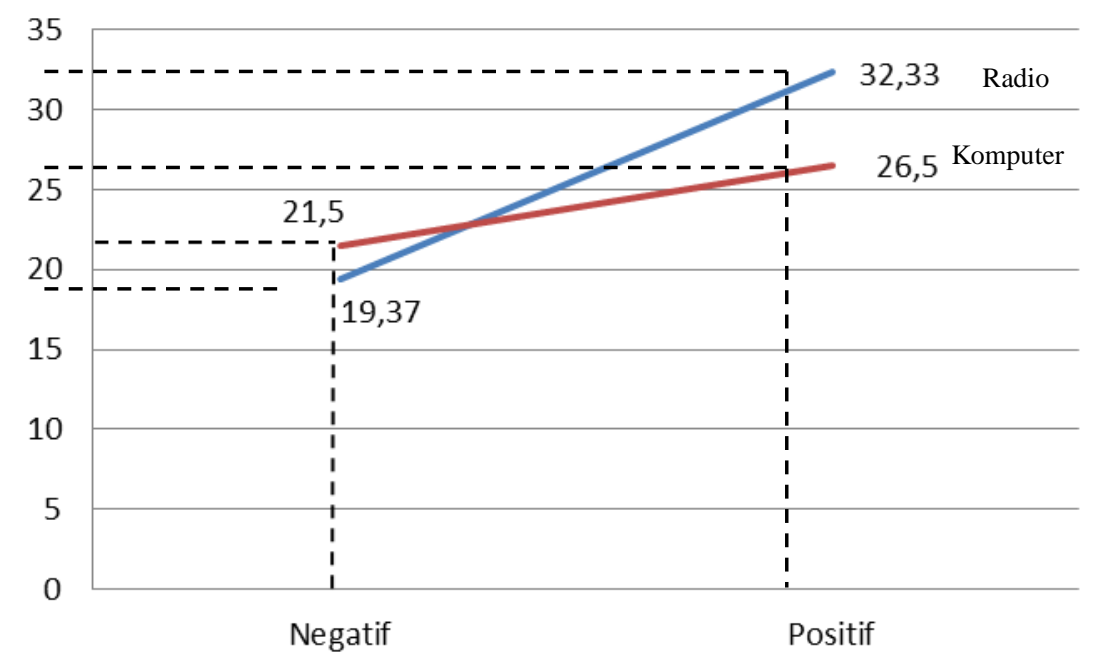

Gambar 1. Interaksi Dua Media Pembelajaran dan Sikap Inovatif terhadap Hasil Belajar TIK

Berdasarkan hasil pengujian hipotesis ketiga yang menyatakan adanya interaksi penggunaan media pembelajaran komputer berbasis radio streaming dengan sikap inovatif, maka perlu dilakukan uji perbedaan rata-rata antara dua proporsi. Gambar 1 menunjukkan pengaruh dan interaksi dari menggunakan media pembelajaran komputer berbasis radio streaming dan sikap inovatif terhadap hasil belajar TIK yang diperoleh siswa, rata-rata hasil belajar TIK siswa yang dibelajarkan dengan menggunakan media pembelajaran komputer berbasis radio streaming lebih tinggi dibandingkan rata-rata hasil belajar siswa dengan menggunakan media pembelajaran berbasis komputer. Pada penelitian ini juga membuktikan faktor sikap inovatif siswa sebagai salah satu karakteristik siswa yang perlu menjadi perhatian karena terbukti bahwa sikap inovatif berpengaruh terhadap hasil belajar TIK di SMK Namira Tech Nusantara.

\section{Pembahasan}

Hasil belajar TIK antara Siswa yang Dibelajarkan dengan Menggunakan Media Pembelajaran Berbasis Radio Streaming dengan Media Pembelajaran Berbasis Komputer. Berdasarkan pengolahan data yang diperoleh bahwa terdapat perbedaan hasil belajar TIK antara siswa yang dibelajarkan dengan media pembelajaran berbasis radio streaming dengan media pembelajaran berbasis komputer, dimana nilai rata-rata TIK siswa yang dibelajarkan dengan media pembelajaran berbasis radio streaming lebih tinggi daripada hasil belajar siswa yang diajar dengan menggunakan media pembelajaran berbasis komputer. Hal ini terbukti adanya peningkatan pemahaman siswa yang menggunakan media pembelajaran berbasis radio streaming dibandingkan dengan media pembelajaran berbasis komputer. Dengan demikian mengajarkan materi TIK akan lebih baik menggunakan media pembelajaran berbasis radio streaming dibandingkan dengan menggunakan media pembelajaran berbasis komputer.

Dari penelitian ini diperoleh rata-rata hasil belajar TIK siswa yang dibelajarkan dengan menggunakan media pembelajaran berbasis radio streaming lebih tinggi daripada hasil belajar TIK siswa yang dibelajarkan dengan media pembelajaran berbasis komputer, meskipun hasil belajar rata-rata siswa antara kedua kelompok tidak terlalu jauh berbeda. Dengan demikian, hasil penelitian yang ditemukan sesuai dengan pendapat yang dikemukakan Sadiman (2003) bahwa media pembelajaran mendukung kegiatan belajar, dimana fungsi atau kegunaan media antara lain: (a) membuat konkrit konsep yang abstrak, (b) membawa obyek yang berbahaya atau sukar didapat ke dalam lingkungan belajar, (c) menampilkan obyek yang terlalu besar, (d) menampilkan obyek yang tidak dapat diamati dengan mata telanjang, (e) mengamati gerakan yang terlalu cepat, (f) memungkinkan siswa berinteraksi langsung dengan lingkungannya, (g) memungkinkan kesegaran pengamatan dan persepsi bagi pengamatan belajar siswa, (h) membangkitkan motivasi belajar, (i) menyajikan informasi belajar secara konsisten 
dan dapat diulangi maupun disimpan menurut kebutuhan, (j) menyajikan pesan atau informasi belajar secara serempak, membatasi batasan waktu maupun ruang, dan (k) mengontrol arah maupun kecepatan belajar siswa. Pemilihan media yang tepat dalam pembelajaran akan membuat siswa semakin memahami dan mendalami isi materi pembelajaran dan berperan aktif untuk mencari dan menggali materi sehingga dapat meningkatkan hasil belajar TIK siswa.

Temuan peneliti ini juga didukung oleh penelitian sebelumnya yang dilakukan oleh Putra (2008) pada siswa MTs yang menunjukkan bahwa penggunaan media interaktif berbasis komputer lebih efektif dalam meningkatkan pengetahuan dan pemahaman siswa dibandingkan dengan menggunakan media konvensional pada mata pelajaran TIK.

Hasil belajar TIK antara siswa yang Memiliki Sikap Inovatif Positif dengan Sikap Inovatif Negatif. Hasil penelitian menunjukkan bahwa rata-rata hasil belajar TIK siswa yang memiliki sikap inovatif positif lebih positif dibandingkan hasil belajar TIK siswa yang memiliki sikap inovatif negatif. Selanjutnya dalam penelitian ini juga terbukti bahwa hasil belajar TIK siswa yang memiliki sikap inovatif positif yang dibelajarkan dengan menggunakan media pembelajaran berbasis radio streaming lebih tinggi daripada hasil belajar TIK siswa yang memiliki sikap inovatif negatif dibandingkan dengan menggunakan media pembelajaran berbasis radio streaming. Hal ini juga berindikasi bahwa siswa yang memiliki sikap inovatif positif lebih mampu memahami materi pelajaran TIK dibandingkan dengan siswa yang memiliki sikap inovatif negatif.

Sikap inovatif siswa merupakan informasi penting yang diperlukan oleh guru, yang dapat dimanfaatkan sebagai dasar untuk menentukan strategi pembelajaran yang sesuai sehingga dapat bermanfaat sebagai dasar untuk menentukan strategi pembelajaran yang sesuai sehingga dapat membantu untuk meningkatkan hasil belajar. Siswa yang memiliki sikap inovatif yang positif akan mampu untuk menciptakan dan mengindentifikasi alternatif-alternatif pemecahan masalah, imajinatif, mampu untuk melakukan berbagai hal serta lancar dalam mengemukakan gagasan-gagasannya. Siswa yang memiliki sikap inovatif yang positif akan mampu untuk menciptakan dan mengindentifikasi

alternatif-alternatif pemecahan masalah, imajinatif, mampu untuk melakukan berbagai hal serta lancar dalam mengemukakan gagasan-gagasannya. Siswa dapat dengan mudah beradaptasi, menyesuaikan apa-apa yang diketahui dengan apa-apa saja yang akan dipelajarinya dalam penyelesaian pembuatan presentasi menggunakan software Ms. Office Powerpoint 2010 setelah mengikuti pembelajaran menggunakan media pembelajaran berbasis komputer yang telah diberikan oleh guru. karena sikap inovatif mampu dalam memecahkan masalah-masalah dari gejalagejala abstrak hingga kekenyataannya. Karena sikap inovatif mampu dalam memecahkan masalah-masalah dari gejala-gejala abstrak hingga kekenyataanya.

Dengan segala kemampuan yang dimilikinya, siswa yang memiliki sikap inovatif positif akan mudah mencapai berbagai kompetensi dasar pada mata pelajaran TIK dibanding dengan siswa yang memiliki sikap inovatif negatif.

Dengan demikian, hasil penelitian yang ditemukan sesuai dengan pendapat yang dikemukakan oleh Hagen dalam Irawati (2003) bahwa sifat-sifat yang menimbulkan kreatif akan menghasilkan kepribadian yang inovatif. Kepribadian yang inovatif adalah: (a) terbuka terhadap pengalaman baru; (b) imajinasi yang kreatif; (c) kesadaran dan tanggung jawab untuk berhasil; dan (d) punya persepsi bahwa dunia mempunyai tantangan. Respon individu terhadap perubahan merupakan keputusan terhadap inovasi, apakah individu menerima atau menolak inovasi tersebut.

Temuan peneliti ini juga didukung oleh penelitian sebelumnya yang dilakukan oleh Karitimi (2004) pada siswa yang memiliki kemampuan yang bervariasi positif, sedang dan negatif dengan menggunakan media pembelajaran berbasis komputer terbukti dapat meningkatkan penguasaan konsep, keterampilan berpikir kreatif dan keterampilan proses sains siswa.

Interaksi antara Menggunakan Media Pembelajaran Berbasis Radio Streaming dan Sikap Inovatif Dalam Mempengaruhi Hasil Belajar TIK. Hasil belajar TIK siswa di SMK Namira Tech Nusantara dipengaruhi oleh media pembelajaran berbasis radio streaming dan sikap inovatif siswa. Media pembelajaran berbasis radio streaming memberi pengaruh yang lebih tinggi dibanding dengan hasil 
belajar dengan menggunakan media pembelajaran berbasis komputer. Dengan berdasarkan hasil temuan pada penelitian dan hasil uji perbandingan ganda dengan uji Scheffe serta beberapa penelitian yang relevan, maka dapat disimpulkan:

Hasil belajar TIK jika dibelajarkan dengan media pembelajaran radio streaming lebih tinggi dibandingkan dengan media pembelajaran komputer. Lucas (2000) menguraikan definisi teknologi informasi, yang dijelaskan sebagai berikut: "Teknologi informasi adalah segala bentuk teknologi yang diterapkan untuk memproses dan mengirimkan informasi dalam bentuk elektronis, mikro komputer, komputer mainframe, pembaca barcode, perangkat lunak pemproses transaksi, perangkat lembar kerja (worksheet), peralatan komunikasi dan jaringan merupakan contoh teknologi informasi". Radio menjadi media pendidikan dalam berbagai aspeknya. Karena media ini memang memiliki potensi dan kekuatan yang amat berpengaruh dalam dunia kependidikan. Radio sebagai pemberi informasi dan alat yang mendidik, muatan sajiannya dapat meningkatkan pengetahuan, keterampilan, moral, dan akhlak seseorang.

Darmanto (2005) menjelaskan fungsi siaran radio pendidikan: (1) meningkatkan kesadaran nasional warga Negara; (2) modernisasi nasional; (3) suplemen bagi pendidikan sekolah; (4) mempercepat penyampaian informasi baru tentang pendidikan kepada sekolah; (5) penyelenggaraan pendidikan bagi semua kalangan dengan isi yang sama untuk skala nasional; (6) menggantikan fungsi kehadiran guru profesional dan profesor; (7) menambah materi pengajaran dan bacaan buku; (8) modernisasi dalam penyampaian materi dan mengembangkan metode mengajar; (9) mengikuti pendidikan kembali bagi guruguru; (10) mencukupkan informasi dan pendidikan bagi kelompok kecil; (11) membantu mereka yang tidak mampu melanjutkan sekolah karena tidak memiliki waktu dan keterbatasan ekonomi; dan (12) persiapan belajar untuk menghadapi ujian nasional.

Dalam pelaksanaanya pembelajaran berbasis komputer dilakukan secara individual oleh masing-masing siswa di laboratorium komputer. Hal ini sangat memberikan keleluasaan pada siswa untuk menggunakan waktu sesuai dengan kebutuhan dan kemampuannya. Bagi siswa yang memiliki kemampuan akan cepat selesai dalam mempelajari konten/materi pelajaran yang diprogramkan dalam pembelajaran berbasis komputer. Tapi yang kurang memiliki kemampuan akan lambat dalam mengerjakan atau memahami konten yang ada dalam pembelajaran berbasis komputer.

Hasil belajar TIK jika menggunakan media pembelajaran berbasis radio streaming lebih tinggi pada siswa yang bersikap inovatif positif dibandingkan dengan siswa yang bersikap inovatif negatif. Menurut Djaali (2007) sikap belajar ikut menentukan intensitas kegiatan belajar. Sikap belajar yang positif akan menimbulkan intensitas kegiatan yang lebih tinggi dibandingkan dengan sikap belajar yang negatif. Peranan sikap dalam hal ini bukan saja ikut menentukan apa yang dilihat seseorang, bagaimana juga ia melihatnya. Berdasarkan apa yang telah dikemukakan sikap belajar yang positif berkaitan erat dengan minat dan motivasi. Siswa yang memiliki sikap positif akan lebih aktif dalam belajar dan dengan demikian akan memperoleh hasil yang lebih baik dibandingkan dengan siswa yang sikap belajarnya negatif. Dengan demikian, hasil belajar TIK dengan media pembelajaran berbasis radio streaming akan lebih mudah dipahami oleh siswa yang memiliki sikap inovatif positif, hal ini sesuai dengan karakteristik siswa yang memiliki sikap inovatif positif cenderung lebih mudah mengikuti cara belajar yang baru.

Meskipun media pembelajaran berbasis radio streaming lebih baik digunakan bagi siswa yang memiliki sikap inovatif positif, namun tidak tertutup kemungkinan dapat juga dipakai oleh siswa yang memiliki sikap inovatif negatif. Hal ini dikarenakan melalui media pembelajaran berbasis radio streaming, siswa dapat mengikuti langkah demi langkah materi pembelajaran secara langsung dan dapat dipraktekkan oleh siswa itu sendiri sehingga media pembelajaran akan mudah dan lebih menyenangkan.

Faktor penyebab pembelajaran berbasis radio streaming lebih tinggi dari media pembelajaran berbasis komputer adalah: (a) menjelaskan terlebih dahulu tujuan dan kompetensi, (b) menentukan dan menjelaskan kebiasaan, ucapan, kecekatan, gerak tertentu dan sebagainya yang akan dilatihkan sehingga siswa mengetahui dengan jelas apa yang harus mereka kerjakan, (c) 
memusatkan perhatian siswa terhadap bahan yang akan atau sedang dilatihkan, (d) adanya selingan latihan, (e) memperhatikan kesalahan-kesalahan yang dilakukan siswa, serta mendiagnosis kesulitan-kesulitan yang dialami oleh siswa dan, (f) latihan tidak boleh terlalu lama atau terlalu cepat.

Hasil belajar TIK jika menggunakan media pembelajaran berbasis komputer lebih tinggi pada siswa yang bersikap inovatif positif dibandingkan dengan siswa yang bersikap inovatif negatif. Mata pelajaran TIK merupakan mata pelajaran yang mengharuskan siswa memiliki sejumlah kompetensi khususnya dalam bidang keterampilan komputer. Kemampuan ini akan lebih mudah diperoleh siswa yang memiliki sikap inovatif positif untuk mudah memahami dan berani mencoba untuk berkreasi dan menangkap isi materi yang dibelajarkan dengan menggunakan media pembelajaran berbasis komputer.

Menurut Rusman, dkk (2011:99-100), keunggulan pembelajaran berbasis komputer adalah penerapan prinsip belajar tuntas atau mastery learning. Dalam pelaksanaan pembelajaran berbasis komputer semua siswa harus dapat menyelesaikan semua pengalaman belajar yang dikemas dalam program pembelajaran berbasis komputer, baik itu berupa pemahaman materi dan tugas mengerjakan tes atau evaluasi yang harus diselesaikan dengan benar. Bila siswa salah dalam mengerjakan soal-soal latihan, maka komputer akan memberikan feedback, bahwa jawaban salah, sehingga siswa harus kembali pada uraian materi yang belum dipahaminya, setelah itu siswa dapat kembali ke soal latihan tadi untuk dikerjakan dengan benar. Dengan demikian, siswa yang memiliki kemampuan inovatif positif akan cepat selesai dalam mempelajari konten/materi pelajaran yang diprogramkan dalam pembelajaran berbasis komputer. Tapi yang memiliki sikap inovatif negatif akan mengalami kesulitan dalam mengerjakan atau memahami konten yang ada.

Hasil belajar TIK jika menggunakan media pembelajaran berbasis radio streaming lebih tinggi pada siswa yang bersikap inovatif negatif dengan siswa yang menggunakan media pembelajaran berbasis komputer yang bersikap inovatif negatif. Pembelajaran TIK akan lebih baik dibelajarkan dengan menggunakan media pembelajaran berbasis radio streaming dibandingkan dengan media pembelajaran berbasis komputer. Hal ini disebabkan karena siswa akan lebih mudah untuk memahami materi dengan cara melakukan pengulangan dengan latihanlatihan pada materi yang diberikan. Dalam media pembelajaran ini dapat pula dipakai sebagai suatu cara mengulangi bahan latihan yang disajikan serta dapat menambah kecepatan. Dengan demikian, siswa yang menggunakan media pembelajaran berbasis komputer yang memiliki sikap inovatif negatif pada umumnya kurang berminat untuk mencoba metode pembelajaran yang baru dan biasanya mereka akan lebih nyaman dengan cara belajar yang konvensional.

Temuan peneliti ini juga didukung oleh penelitian sebelumnya yang dilakukan oleh Resien (2009) pada siswa SMA Methodis yang menggunakan dua media pembelajaran, yaitu media pembelajaran interaktif latihan dan praktik dan media pembelajaran interaktif tutorial yang terbukti meningkatkan hasil belajar TIK siswa yang bersikap inovatif positif dan negatif.

\section{PENUTUP \\ Simpulan}

Berdasarkan hasil penelitian dan pembahasan yang dikemukakan sebelumnya, maka dapat disimpulkan bahwa:

1. Hasil belajar TIK siswa yang dibelajarkan dengan menggunakan media pembelajaran berbasis radio streaming lebih tinggi dibandingkan dengan hasil belajar TIK siswa yang dibelajarkan dengan menggunakan media pembelajaran berbasis komputer.

2. Hasil belajar TIK siswa yang memiliki sikap inovatif positif lebih tinggi daripada hasil belajar TIK siswa yang memiliki sikap inovatif negatif.

3. Terdapat interaksi antara media pembelajaran berbasis radio streaming dalam pembelajaran dengan sikap inovatif siswa terhadap hasil belajar TIK, artinya bahwa siswa yang memiliki sikap inovatif positif dengan menggunakan media pembelajaran berbasis radio streaming maupun komputer akan memiliki hasil belajar TIK lebih tinggi dibandingkan dengan siswa yang memiliki sikap inovatif negatif .

\section{Saran}


Berdasarkan simpulan dan implikasi seperti yang telah dikemukakan, maka disarankan beberapa hal berikut ini:

1. Diharapkan untuk mampu memahami materi yang diberikan dengan menggunakan media SAM Broadcaster. Pembelajaran menggunakan media ini diharapkan di dalam diri siswa sendiri memiliki motivasi, kemauan dan kemampuan dalam menggunakan dan memanfaatkan teknologi yang ada. Oleh karena itu, disarankan kepada guru mata pelajaran TIK agar menggunakan media pembelajaran berbasis radio streaming.

2. Untuk meningkatkan hasil belajar TIK siswa yang memiliki sikap inovatif tinggi, disarankan untuk menggunakan media pembelajaran berbasis radio streaming melalui software SAM Broadcaster karena sesuai dengan karakteristik siswa tersebut. Meskipun menggunakan media pembelajaran berbasis radio streaming lebih cocok dengan siswa yang memiliki sikap inovatif tinggi, namun disarankan kepada guru untuk memanfaatkan media ini juga kepada siswa yang memiliki sikap inovatif rendah, karena dengan melakukan pembelajaran ini siswa akan terusmenerus melakukan latihan dan praktik. Dan juga tidak tertutup kemungkinan siswa juga dapat menggunakan media pembelajaran berbasis komputer dalam pembelajaran TIK.

3. Kepada guru mata pelajaran TIK untuk mampu merancang atau mengembangkan media pembelajaran yang berkaitan dengan mata pelajaran TIK. Disarankan kepada guru-guru untuk lebih aktif dan kreatif dalam memilih berbagai media pembelajaran yang variatif dalam menyampaikan materi pembelajaran, sehingga media-media pembelajaran yang digunakan dapat disesuaikan dengan karakteristik siswa dan mata pelajaran itu sendiri. Penggunaan media pembelajaran berbasis radio streaming dengan menggunakan software SAM Broadcaster pada penelitian ini dapat dijadikan sebagai salah satu alternatif bagi guru untuk menyampaikan pembelajaran kepada siswa SMA.

4. Sekolah disarankan untuk dapat menyediakan sarana media pembelajaran yang lebih baik lagi untuk peningkatan kualitas pembelajaran TIK. Guru-guru perlu dibekali dengan kemampuan untuk memanfaatkan teknologi yang ada di dalam memberikan pembelajaran, yaitu dengan memberikan pelatihan atau sosialisasi pemakaian media.

5. Untuk peneliti berikutnya supaya dapat menggunakan populasi dan sampel yang lebih besar lagi. Dengan semakin besar anggota sampel yang digunakan akan semakin mengecilkan tingkat kesalahan dan meningkatkan tingkat ketelitian atau kepercayaan hasil dari penelitian.

\section{DAFTAR PUSTAKA}

Arsyad, A. (2009). Media Pembelajaran. Jakarta: Rajawali Press.

Badiran, M. (2008). Alternatif Pembelajaran Era Digita. Makalah Seminar Nasional: di Unimed.

Briggs, Leslie, J., (1977). Intructional Design, Principle and Aplication. NewYork: Mc.Graw- Hill Book Company

Dapur internet, (2009). Streaming: Membuat File Besar Serasa Kecil. Diambil dari: http://www.dapurinternet.com/web/inde x2.php?option=com_content\&do _pdf $=1 \& i d=26$ diakses 1 Maret 2009.

Djamarah, S.B. (2006). Strategi Belajar Mengajar. Jakarta: Rineka Cipta.

Faturrahman, P., dan Sutikno (2007). Strategi Belajar Mengajar Melalui Penanaman Konsep Umum Dan Konsep Islami, Bandung: Penerbit Refika Aditama.

Gagne, R. M. (1985). The Condition of Learning and Theory of Instruction, $4^{\text {th }}$ ed. New York: CBS College Publishing.

Gagne, R.M., Briggs, L.J \& Wager, W.W. (1988). Principles of Instruction Design, $3^{\text {rd }}$ edition. New York: Saunders College Publishing.

Hartono dan Gideon. (2009). "Implementasi Real Time Streaming Protocol Untuk Aplikasi Radio Internet". Techné Jurnal Ilmiah Elektroteknika (Vol. 8 No. 1).

Heinich, R., Molenda, M., Russell, J. D., \& Smaldino, S.E. (2002). Instructional Media and Technology for Learning, $7^{\text {th }}$ edition. New Jersey: Prentice Hall, Inc.

Joyce, B., dan Weil, M., (2009). Models of Teaching. Yogyakarta: Pustaka Pelajar.

Kleiner, A, (2002). Karen Stephenson's Quantum Theory of Trust. dari: http://www.netform.com/html/s+b\%20a rticle.pdf. Diambil tanggal 10 Desember 2007 
Latuheru, D. John, M.P (1998). Media Pembelajaran dalam Proses Belajar Mengajar Masa Kini. Jakarta: Depdikbud

Lucas, Henry. C. (2000). Analisis, Disain dan Implementasi Sistem Informasi. Jakarta: Erlangga

M. Dell'Olio, J., dan Tony D. (2007). Models of Teaching. USA: Sage Publications.

Mayer, Ricard, E. (2009). Multimedia Learning (Second Edition). United State Of America: Cambridge University Press.

Munadi, Y. (2008). Media Pembelajaran Sebuah Pendekatan Baru. Jakarta: Gaung Persada Press.

Munir. (2008). Kurikulum Berbasis TIK. SPs Universitas Pendidikan Indonesia.

Nurwulan, Ayu Isni dan Paputungan, Irving Vitra. (2009). Makalah Seminar Nasional: Perancangan Radio Streaming Edukasi (Studi Kasus Balai Pengembangan Media Radio Yogyakarta).

Prastowo, Andi. (2011). Panduan Kreatif Membuat Bahan Ajar Inovatif: Menciptakan Metode Pembelajaran yang Menarik dan Menyenangkan. Jogjakarta: Diva Press.

Rusman. (2011). Model-model Pembelajaran: Mengembangkan Profesionalisme Guru. Jakarta: PT. Rajawali Pers.

Rusman, dkk., (2011). Pembelajaran Berbasis Teknologi Informasi dan Komunikasi: Mengembangkan Profesionalisme Guru. Jakarta: PT Raja Grafindo Persada.

Sadiman, A.S. (1986). Media Pendidikan: Pengeratian Pengembangan, dan Pemanfaatannya. Jakarta: CV. Rajawali.

Sardiman. (2010). Interaksi dan Motivasi Belajar Mengajar. Jakarta: Penerbit Grafindo.

Sanjaya, Wina. (2010). Strategi Pembelajaran Berorientasi Standar Proses Pendidikan. Jakarta: Prenada Media Group.

Schramm, W., (1977). Big Media, Little Media: Tools and Technologies for Instruction. NewYork: Mc.Graw-Hill Book Company

Siemen, G. (2005). Connectivisme: A learning theory for digital age.International journal of Instructional Technology and Distance Learning. (Vol. 12. No.1).
Slameto. (2003). Belajar dan Faktor-Faktor Yang Mempengaruhinya. Jakarta: Penerbit Rineka Cipta.

Soekartawi. (2003). E-Learning di Indonesia dan Prospeknya di Masa Mendatang. Makalah disampaikan pada Seminar Nasional E-Learning Perlu E-Library di Universitas Kristen Petra Surabaya.

Sumiati, dan Asra. (2009). Metode Pembelajaran. Bandung: CV. Wacana Prima.

Susilana, Rudi dan Riyana, Cepi. (2009). Media Pembelajaran: Hakikat, Pengembangan, Pemanfaatan dan Penilaian. Bandung: CV. Wacana rima.

Sutikno, M.S. (2009). Belajar dan Pembelajaran. Bandung : Pressport.

Sutrisno. (2011). Pengantar Pembelajaran Inovatif Berbasis Teknologi Informasi \& Komunikasi. Jakarta: Gunung Persada (GP) Press.

Syarifuddin, dan Nasution. I (2005). Manajemen Pembelajaran. Ciputat: Penerbit Quantum Teaching.

Trianto. (2007). Mendesain Model-Model Pembelajaran Inovatif Berorientasi Konstruktivistik. Jakarta: Prestasi Pustaka.

Warsita, B. (2008). Teknologi Pembelajaran, Landasan dan Aplikasinya. Jakarta: Rineka Cipta.

Wallington, C.J. (1996). Media Production: Production of Still Media. Plomp, T., \& Ely, D.P. (Eds.): International Encyclopedia of Educational Technology, $2^{\text {nd }}$ edition. New York: Elsevier Science, Inc. 